\title{
Detection of epistasis through triple test cross (TTC) analysis in maize (Zea mays L.)
}

\author{
R. Pavan*, E. Gangappa, S. Ramesh, A. Mohan Rao and Hittalmani Shailaja \\ Department of Genetics and Plant Breeding, University of Agricultural Sciences, Bangalore -560065 (Karnataka), INDIA \\ *Corresponding author E-mail: pavan_55agri@rediffmail.com
}

Received: May 7, 2017; Revised received: June 20, 2017; Accepted: November 10, 2017

\begin{abstract}
The present study was carried out to detect the epistasis present in two cross of maize through triple test cross (TTC) analysis. The mean squares due to total epistasis was highly significant at $\mathrm{P} \leq 0.01$ for all the characters in both C-I and C-II, except for ear length in C-I. The $i$ type of epistasis was highly significant for the traitssuch as days totasseling, days to silking, earlength, ear circumference, kernels row $^{-1}, 100$ grain weight and shelling percentage in C-I and in C-II, ' $\bar{l}$ type was non-significant for ASI, ear length, kernels row ${ }^{-1}$ and grain yield plot ${ }^{-1}$. Both $j$ type and $I$ type of epistasis weresignificant for all characters in both C-I and C-II, except for ear length in C-I and days to silking in C-II.The estimate of additive genetic component (D) was highly significant for all characters in both C-I and C-II. Epistasis played a significant role in the inheritance of all the characters in both C-I and C-II except for ear length in C-I. Both additive and dominance components of genetic variance with a predominance of dominance genetic variance played an important role in the inheritance of all the quantitative traits except ear length in C-I and kernel rows ear ${ }^{-1}$ in $\mathrm{C}-\mathrm{II}$.
\end{abstract}

Keywords: Additive, dominance, epistasis, genetic variance, Triple test cross analysis

\section{INTRODUCTION}

Maize is an important cereal crop of the world. It is considered as a model crop because it possesses enormous genetic variability which is coupled with its biological diversity. Maize breeders have been successfully used the genetic variability to exploited heterosis by crossing inbreed lines to develop hybrids. Expression of heterosis mainly depends upon the nature and extent of genetic component of variation. Thus there is need for through realizing of genetic variation, levels of dominance, and the importance of genetic effects for better understanding of the gene action involved in the expression of heterosis. Several biometrical methods are available for obtaining information on the nature of genetic variation. Triple test cross analysis proposed by Kearsey and Jinks ( 1968) is considered as most efficient and useful biometrical techeniques for detecting epistasis and in the absence of epistasis, it provides unambiguous estimates of additive and dominance componentsgene frequencies and linkage relationships. Further, TTC design is independent of both the gene frequencies and the mating system of the population to be investigated. In addition, TTC has the widest applicability as it can be used to investigate both segregating and non-segregating populations arising from different generations $\left(\mathrm{F}_{2}\right.$, backcross and homozygous lines) (Kearsey and Jinks, 1968; Jinks et al., 1969; Jinks and Perkins, 1970; Chahal and Jinks, 1978). Keeping this points in view, present study was undertaken to detect epistasis for grain yield, its components and anthesis-silking interval in maize.

\section{MATERIALS AND METHODS}

Triple test cross (TTC) design (Kearsey and Jinks, 1968) was used to detect epistasis governing economic traits. The basic material for the study comprised of three inbred linesviz., DMRN 21, HKI-26-24-(1-2) and CML 41 and there salient features are presented in Table 1.

Two $F_{1}$ crosses $(\mathrm{C}-\mathrm{I}) \mathrm{HKI}-26-2-4-(1-2) \times$ CML 41 and (C-II) DMRN $21 \times$ HKI 26-24(1-2) contrasting for grain yield and ASI, respectively were effected at Kblock of the Department of Genetics and Plant Breeding, University of Agricultural Sciences, Bangalore, during 2012 summer. The two $F_{1}$ 's were sown and selfed to obtain $\mathrm{F}_{2}$ populations during 2012 kharif. A $100 \mathrm{~F}_{2}$ plants were maintained in each of the two crosses. A total of 21 randomly selected $F_{2}$ plants from both the crosses were backcrossed, as male parent to their respective parents as well as their $F_{1}$ 's in farmer's field at Sabbenahalli, Chickballapur district (Zone 5) during 2012 rabi. The 126 TTC progeny families of the two crosses were evaluated in $4 \mathrm{~m}$ row with a spacing of $60 \times 30 \mathrm{~cm}$ in 4 rows each over two seasons in farmer's field at Sabbenahalli, Chickballapur district (Zone 5) during 2013 summer and 2014 summer. All the recommended crop production and protection practices were followed to raisea healthy crop. Dataon 12 different quantitative traits were recorded on randomly labelled 26 plants in each of the 126 TTC progenies. 


\section{RESULTS AND DISCUSSION}

Inthe present study, TTC analysis was carried out in two crosses derived by crossing parents contrasting for grain yield and ASI in maize. Analysis of variance $\left.\overline{\left(\overline{L_{1 \mathrm{i}}}\right.}+\overline{\mathrm{L}_{2 \mathrm{i}}} 2 \overline{\mathrm{L}_{3 \mathrm{i}}}\right)$ due to epistasis indicated the presence of digenicepistatic gene interaction in the expression of all the traits in both crosses except ear length in C-I (Table 2). These results emphasized the inadequacy of additive and dominance gene model and the importance of epistasis in the inheritance of the characters. Wolf and Hallauer (1997, Kalla et al. (2001), Kumar and Gupta (2002), Azizi and Rezaie (2006), Sofiet al. (2006), Sofiet al. (2007), Jin Ming Hua et al. (2008), Singh and Gupta (2008) and Nehvi et al. (2009) reported importance of epistasis in the inheritance of economic traits of maize.

Significance of ' $i$ ' type epistatic interaction (additive $x$ additive) suggested effectiveness of selection in early segregating generation for the improvement of all characters except ASI, plant height, ear height, kernel rows ear ${ }^{-1}$ and grain yield plant ${ }^{-1}$ in C-I and ASI, ear length, kernels row ${ }^{-1}$ and grain yield plot $^{-1}$ in C-II. Both ' $i$ ' type and $(j+l)$ type of epistasis were important in the expression of a few characters such as, days to tasseling, days to silking, ear circumference, kernels row ${ }^{-1}, 100$ grain weight and shelling per cent in C-I and days to tasseling, plant height, ear height, ear circumference, kernel rows ear ${ }^{-1}, 100$ grain weight and shelling per cent in C-II. However, the magnitude of ' $i$ ' type of epistasis was larger than that of $(j+l)$ type of epistasis in both the crosses except for ASI, plant height, ear height, kernel rows ear $^{-1}$ and grain yield plot $^{-1}$ in C-I and for ASI, kernels row ${ }^{-1}$, grain yield plot ${ }^{-1}$ and shelling per cent in C-II. The importance of additive $\times$ additive type of epistasis has been amply demonstrated by several researchers such as Sofiet al. (2006), Rao and Singh (2006) and Hassan Sheret al. (2012) in maize

Detection of additive and dominance components of genetic variance: Significant mean squares due to sums $\overline{\left(\overline{\bar{T}_{1 i}}+\overline{T_{2 i}}\right)}$ and differences $\overline{\left(\overline{\bar{L}_{1 i}}-\overline{\mathrm{L}_{2 i}}\right)}$ for 12 traits (Table 3), indicated presence of both additive and dominance components of genetic variance in the

Table 1. Salient features of parents used for generation of TTC progenies .

\begin{tabular}{|c|c|c|c|}
\hline $\begin{array}{l}\text { Sl. } \\
\text { No }\end{array}$ & Parents & Grain yield & ASI \\
\hline 1 & DMRN 21 & $\begin{array}{c}\text { High } \\
(0.15 \mathrm{~kg} / \text { plant })\end{array}$ & $\begin{array}{c}\text { Low } \\
\text { (1.95 days) }\end{array}$ \\
\hline 2 & $\begin{array}{l}\text { HKI-26-2-4- } \\
(1-2)\end{array}$ & $\begin{array}{c}\text { Low } \\
(0.074 \mathrm{~kg} / \text { plant })\end{array}$ & $\begin{array}{l}\text { High } \\
\text { (7.65 days) }\end{array}$ \\
\hline 3 & CML 41 & $\begin{array}{c}\text { High } \\
\text { (0.22 kg/plant) }\end{array}$ & $\begin{array}{c}\text { Low } \\
\text { (3.2 days) }\end{array}$ \\
\hline
\end{tabular}

inheritance of all the characters except ear length in C-I and kernel rows ear ${ }^{-1}$ in C-II. The present results are in agreement with those of Kalla et al. (2001), Kumar and Gupta (2002), Sofi et al. (2006), Sofi et al. (2007), Jin Ming Hua et al. (2008) in maize. It is known that only additive genetic variation is the fixable variations that ensure the effectiveness of selection for desirable traits. Therefore, reliance should mainly be placed on mass selection or inter-population selection or progeny selection or family selection in order to congregate superior genes for the improvement of aforesaid characters. Isolation of high yielding homozygous lines (varieties) in advanced segregating generations is the most effective breeding method.

Dominance component of genetic variance was predominant in the inheritance of all the traits in both the crosses (Table 4). Any type of selection scheme would fail to achieve higher expression of these traits; however, a hybrid programme in general is expected to be most effective. Reciprocal recurrent selection of Comstock et al. (1949) is expected to be the most effective breeding method for the improvement of the characters which are under the influence of dominant gene action. Earlier researchers such as Kumar and Gupta (2002) and Rao and Singh (2006) have also reported major role of dominance gene action and also recommended recurrent selection schemes for the improvement of the traits in maize.

Direction of dominance: One further useful statistic that could be estimated which was not discussed by Kearsey and Jinks (1968) but explained by Beddowet al. (1962) is the $\mathrm{F}$ value. $\mathrm{F}$ is the covariance of sums

$\left(\overline{L_{1 \mathrm{i}}}+\overline{\mathrm{L}_{2 \mathrm{i}}}\right)$ and differences $\left(\overline{\mathrm{T}_{11}}-\overline{\mathrm{T}_{2 \mathrm{i}}}\right) . \mathrm{F}$ has the same coefficient as additive and dominance genetic variance but it measures the sum of the products of the additive effects (d) and dominance (h) genetic effects at the loci controlling the inheritance of target traits. Both the magnitude and the sign of the covariance provide information about the magnitude and direction of dominance. To determine whether or not the covariance is significant, it was converted into a correlation coefficient with (n-3) degrees of freedom. Thus, direction of dominance and relative frequency of genes with increasing and decreasing effects in the parents was inferred from the following different combination of estimates of ' $\sigma_{d}^{2}$ ' and ' $F$ '.

Both ' $\sigma_{d}{ }_{d}$ ' and ' $F$ ' are significant: Both $\sigma^{2}{ }_{d}$ and $F$ were significant for kernel rows ear ${ }^{-1}$ and shelling per cent inC-I, but they were non-significant for all the traits in C-IIwhich indicated that the traits are under the influence of unidirectional dominance in the inheritance of the traits.

' $\sigma_{d}^{2}$ ' significant and ' $F$ ' non-significant : The estimate of $F$ was non-significant while $\sigma^{2}{ }_{d}$ was significant for all the traits except kernel rows ear ${ }^{-1}$ and shelling per cent in C-I. In C-II the estimates of F and ' $\sigma_{\mathrm{d}}^{2}$ ' were significant for all the traits except kernel 
R. Pavan et al. / J. Appl. \& Nat. Sci. 9 (4): 2496 - 2501 (2017)
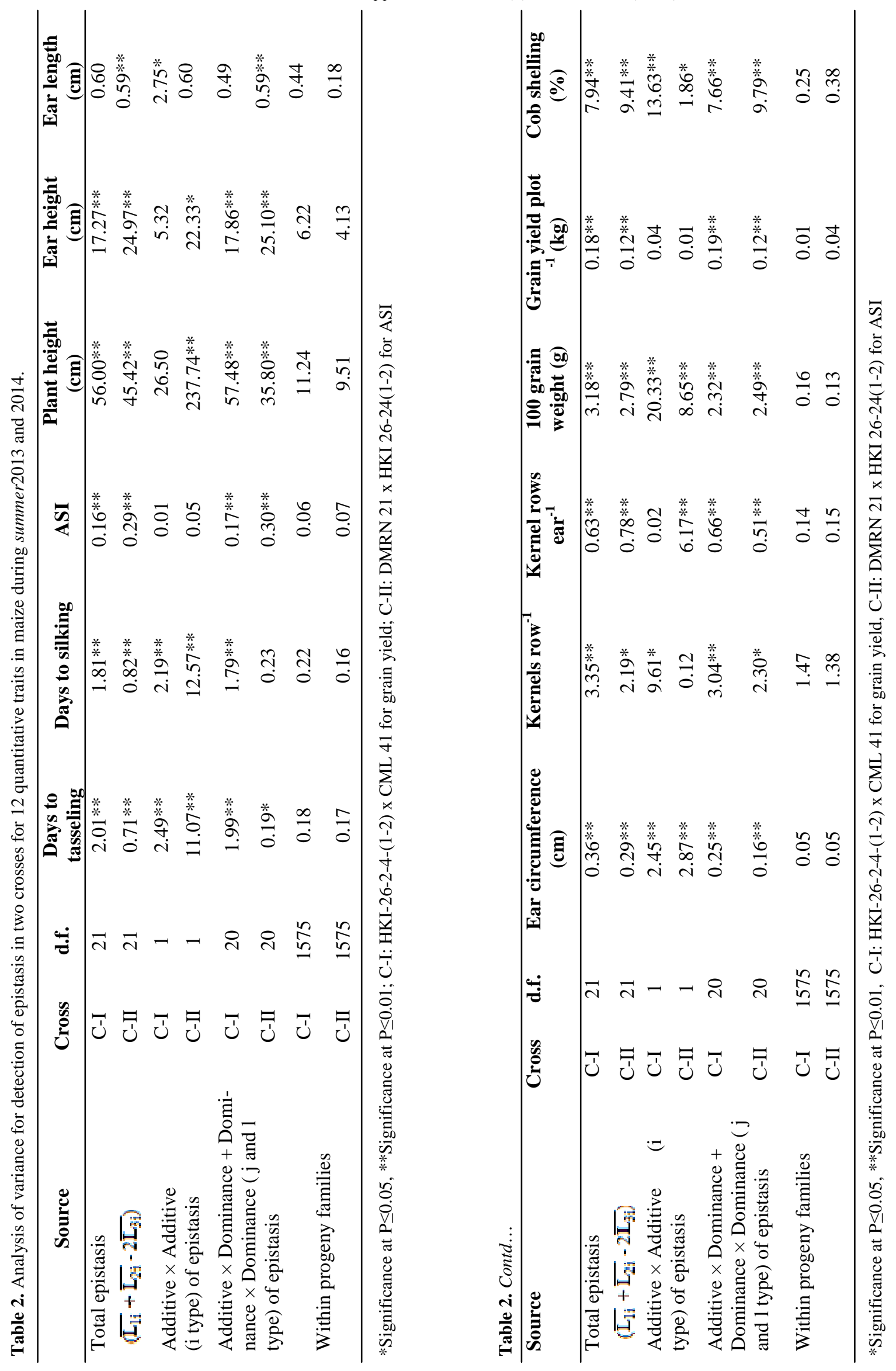

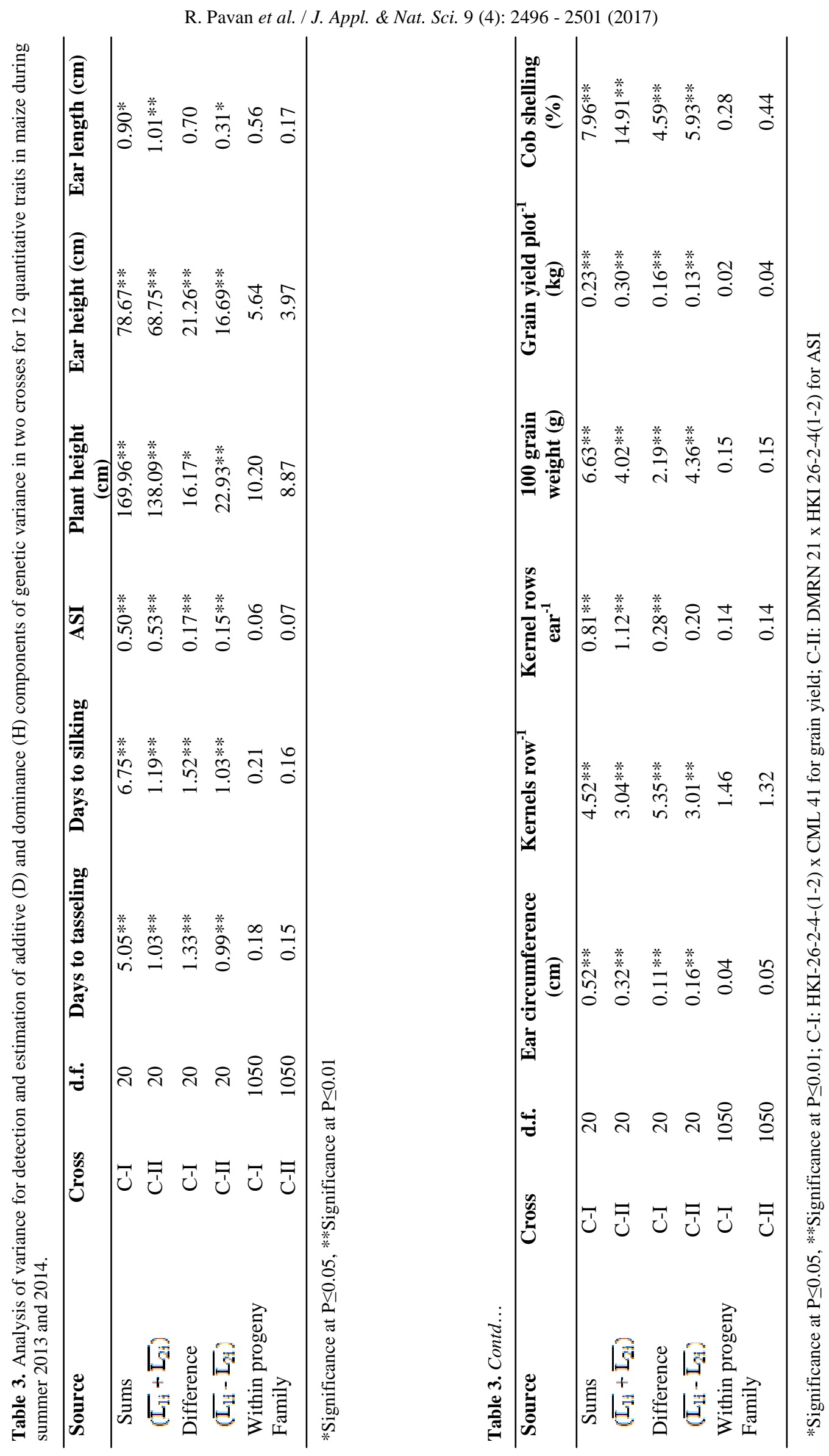
Table 4. Estimates of additive (D) and dominance $(\mathrm{H})$ components of genotypic variance for 12 quantitative traits in two crosses in maize during summer 2013 and 2014.

\begin{tabular}{lccccccc}
\hline $\begin{array}{l}\text { Genetic } \\
\text { parameters }\end{array}$ & Cross & $\begin{array}{c}\text { Days to } \\
\text { tasseling }\end{array}$ & $\begin{array}{c}\text { Days to } \\
\text { Silking }\end{array}$ & ASI & $\begin{array}{c}\text { Plant } \\
\text { height } \\
(\mathbf{c m})\end{array}$ & $\begin{array}{c}\text { Ear } \\
\text { height } \\
(\mathbf{c m})\end{array}$ & $\begin{array}{c}\text { Ear length } \\
(\mathbf{c m})\end{array}$ \\
\hline $\mathrm{D}$ & $\mathrm{C}-\mathrm{I}$ & $19.47^{* *}$ & $26.16^{* *}$ & $1.79^{* *}$ & $639.03^{* *}$ & $292.14^{* *}$ & $1.33^{*}$ \\
& $\mathrm{C}-\mathrm{II}$ & $3.52^{* *}$ & $4.14^{* *}$ & $1.84^{* *}$ & $516.91^{* *}$ & $259.10^{* *}$ & $3.36^{* *}$ \\
$\mathrm{H}$ & $\mathrm{C}-\mathrm{I}$ & $4.59^{* *}$ & $5.24^{* *}$ & $0.47^{* *}$ & $23.89^{*}$ & $62.49^{* *}$ & 0.54 \\
& $\mathrm{C}-\mathrm{II}$ & $3.34^{* *}$ & $3.50^{* *}$ & $0.33^{* *}$ & $56.25^{* *}$ & $50.86^{* *}$ & $0.58^{*}$ \\
$(\mathrm{H} / \mathrm{D})^{1 / 2}$ & $\mathrm{C}-\mathrm{I}$ & 0.49 & 0.45 & 0.51 & 0.19 & 0.46 & 0.64 \\
& $\mathrm{C}-\mathrm{II}$ & 0.98 & 0.92 & 0.42 & 0.33 & 0.44 & 0.41 \\
$\mathrm{~F}$ & $\mathrm{C}-\mathrm{I}$ & 21.42 & 22.97 & 2.45 & 163.09 & 259.84 & 0.54 \\
& $\mathrm{C}-\mathrm{II}$ & -2.77 & 0.70 & 1.17 & 240.51 & 184.39 & -1.95 \\
$\mathrm{r}($ Sums / & $\mathrm{C}-\mathrm{I}$ & -0.52 & -0.45 & -0.52 & -0.19 & -0.40 & -0.04 \\
Difference) & $\mathrm{C}-\mathrm{II}$ & 0.17 & -0.40 & -0.26 & -0.27 & -0.34 & 0.22 \\
\hline
\end{tabular}

*Significance at $\mathrm{P} \leq 0.05, * *$ Significance at $\mathrm{P} \leq 0.01$; C-I: HKI-26-2-4-(1-2) x CML 41 for grain yield; C-II: DMRN 21 x HKI 26 $-2-4(1-2)$ for ASI

Table 4. Contd...

\begin{tabular}{|c|c|c|c|c|c|c|c|}
\hline $\begin{array}{l}\text { Genetic } \\
\text { parameters }\end{array}$ & Cross & $\begin{array}{c}\text { Ear } \\
\text { circumference } \\
(\mathrm{cm})\end{array}$ & $\begin{array}{c}\text { Kernels } \\
\text { row }^{-1}\end{array}$ & $\begin{array}{c}\text { Kernel } \\
\text { rows ear }^{-1}\end{array}$ & $\begin{array}{l}100 \text { grain } \\
\text { weight }(\mathrm{g})\end{array}$ & $\begin{array}{c}\text { Grain yield } \\
\text { plot }^{-1}(\mathrm{~kg})\end{array}$ & $\begin{array}{c}\text { Cob shelling } \\
(\%)\end{array}$ \\
\hline \multirow[t]{2}{*}{$\mathrm{D}$} & C-I & $1.89 * *$ & $12.25 * *$ & $2.70^{* * *}$ & $25.94 * *$ & $0.84 * *$ & $30.73 * *$ \\
\hline & C-II & $1.09 * *$ & $6.88 * *$ & $3.93 * *$ & $15.47 * *$ & $1.07 * *$ & $57.87 * *$ \\
\hline \multirow[t]{2}{*}{$\mathrm{H}$} & C-I & $0.29 * *$ & $15.54 * *$ & $0.57 * *$ & $8.16^{* *}$ & $0.58 * *$ & $17.23 * *$ \\
\hline & C-II & $0.44 * *$ & $6.77 * *$ & 0.24 & $16.83 * *$ & $0.36 * *$ & $21.96 * *$ \\
\hline \multirow[t]{2}{*}{$(\mathrm{H} / \mathrm{D})^{1 / 2}$} & C-I & 0.39 & 1.13 & 0.46 & 0.56 & 0.83 & 0.75 \\
\hline & C-II & 0.64 & 0.99 & 0.25 & 1.04 & 0.58 & 0.62 \\
\hline \multirow[t]{2}{*}{$\mathrm{F}$} & C-I & -0.37 & -33.50 & $-5.26 * *$ & 20.61 & 1.21 & $-43.44 *$ \\
\hline & C-II & -0.98 & -14.55 & 0.13 & 2.08 & -0.63 & -66.47 \\
\hline \multirow{2}{*}{$\begin{array}{l}\text { r (Sums / } \\
\text { Difference) }\end{array}$} & C-I & 0.10 & 0.43 & $0.69 * *$ & -0.34 & -0.40 & $0.44 *$ \\
\hline & C-II & 0.27 & 0.30 & -0.02 & -0.03 & 0.20 & 0.44 \\
\hline
\end{tabular}

*Significance at $\mathrm{P} \leq 0.05$, **Significance at $\mathrm{P} \leq 0.01$; C-I: HKI-26-2-4-(1-2) x CML 41 for grain yield; C-II: DMRN 21 x HKI 262-4(1-2) for ASI

rows ear ${ }^{-1}$. These results indicated bidirectional dominance in the inheritance of the aforesaid traits. Further, both increasing and decreasing alleles were dominant and recessive to the same extent as revealed from significant ' $\sigma_{\mathrm{d}}^{2}$ ' and non-significant ' $F$ ' value.

Both ' $\sigma^{2}{ }_{d}$ 'and ' $F$ ' were non- significant: Both $\sigma^{2}{ }_{d}$ and $\mathrm{F}$ were non-significant for ear length in $\mathrm{C}$-I and for kernel rows ear ${ }^{-1}$ in $\mathrm{C}$-II suggesting ambidirectional dominance and decreasing alleles are more often dominant than increasing alleles.

' $\sigma_{d}^{2}$ ' non-significant and ' $F$ ' significant: This type of situation was not witnessed for any character in both the crosses. Moreover, such type of combination would appear only when there is sampling error.

\section{Conclusion}

In the present study, epistasis played a significant role in the inheritance of all the characters in both C-I and C-II except for ear length in C-I. Both additive and dominance components of genetic variance with a predominance of dominance genetic variance played an important role in the inheritance of all the quantitative traits except ear length in C-I and kernel rows ear ${ }^{-1}$ in C-II. Since epistasis was detected for most of the traits, it is hereby inferred that estimation of genetic components of variation by models assuming absence of epistasis would be significantly biased and can cause consequent bias in estimates of heritability and other genetic parameters. However, as of now, there is no conclusive evidence about the extent of bias and the effect of epistasis on the expression of quantitative traits. Studies for assessment of relative importance of epistatic component 
need to be carried out by developing appropriate genetic modes.

\section{REFERENCES}

Azizi, F. and Rezaie, A. (2006). Epistasis effects of yield and some morphological traits in maize by triple testcross. Seed and Plant, 22: 237-255.

Beddow, A. R., Breese, E. L. and Lewis, B. (1962). The genetic assessment of heterozygous breeding material by means of a diallel cross. I. Description of parents, self- and cross-fertility and early seedling vigour. Heredity, 17: 501-512.

Comstock, E., Robinson, H. F. and Harvey, P. H.(1949). A breeding procedure designed to make maximum use of both general and specific combining ability. Agronomy Journal, 41: 360-367.

Chahal, G. S. and Jinks, J. L. (1978). A general method of detecting the additive, dominance and epistatic variation that inbred lines can generate using a single tester. Heredity, 40: 117-125.

Hassan-Sher., Muhammad-Iqbal., Kiramat-Khan., MuhammadYasir., Hameed-ur-Rahman- (2012). Genetic analysis of maturity and flowering characteristics in maize (Zea mays L.). Asian Pacific Journal of Tropical Biomedicine, 2: 621-626.

Jinks, J. L., Perkins, J. M., Breese, B. L. (1969). A general method of detecting additive, dominance and epistatic variation for metrical traits. II: Application to inbred lines, Heredity, 24: 45-57.

Jinks, J. L, and Perkins, J. M. (1970). A general method for the detection of additive, dominance and epistatic components of variation. III. $\mathrm{F}_{2}$ and backcross populations. Heredity, 25: 419-429.
Jin Ming Hua., Li Ji Zhu., Wang Yong., Yu Xiao Dong., Wen Wei and Yang Wei Guang. (2008), Genetic studies on kernel length of maize. Journal of Jilin Agricultural University. 30: 119-121.

Kalla, V., Kumar, R and Basandrai, A. K. (2001). Combining ability analysis and gene action estimates of yield and yield contributing characters in maize (Zea mays L.). Crop Research., 22:102-106.

Kearsey, M. J. and Jinks, J. L. (1968). A general method of detecting additive, dominance and epistatic variation for metrical traits. I: Theory. Heredity, 23:403-409.

Kumar, P. and Gupta, S. C.(2002), Inheritance of some quantitative traits in maize. Annals of Agricultural Sciences, 23: 96-100.

Nehvi, F. A., Iqbal Asif, M., Wani Shafiq, A., Lone Ajaz, A. and Khan, M. A. (2009). Triple test cross analysis in maize (Zea Mays L.). Crop Improvement.,36(1): 25-28.

Rao, M. S, and Singh, R. D. (2006). Genetic studies on plant, maturity and physiological characters of maize (Zea mays L.) under rainfed and irrigated conditions, Plant breeding in post genomics era. In: Proceedings of Second National Plant Breeding Congress, Coimbatore, India,-1-3-March,-2006. 153-159.

Singh, S. B. and Gupta, B. B. (2008). Triple test cross analysis to detect of epistasis for morpho-physiological traits related to drought tolerance and yield components in maize (Zea mays L.). Journal of Research. 7(2): 202209.

Sofi, P., Rather, A. G. and Venkatesh, S. (2006). Triple test cross analysis in maize (Zea mays L.). Indian Journal of Crop Science. 1(1-2): 191-193.

Sofi, P., Rather, A. G. and Zahoor. D. (2007). Association of heterotic expression for grain yield and its component traits in maize (Zea mays L). International Journal of Agricultural Research.2(5): 500-503.

Wolf, D. P. and Hallauer, A. R. (1997). Triple testcross analysis to detect epistasis in maize. Crop Science. 37 (3): 763-770. 